Sri Lankan J. Biol. 2021, 6 (1): 31 - 39

DOI: http://doi.org/10.4038/sljb.v6i1.60

https://orcid.org/0000-0001-9362-1452

Research Article

Open Access

\title{
Lice infestation in village chicken and management practices of keepers in Ilorin, North Central Nigeria
}

\author{
Opeyemi, O.A ${ }^{1^{*}}$., Shittu, O ${ }^{1}$, Kadir, R.A ${ }^{2}$., Kayode, A. E ${ }^{1}$., Yusuf, $\mathrm{K}^{1}$. \\ ${ }^{1}$ Parasitology Unit, Department of Zoology, University of Ilorin, Nigeria. \\ ${ }^{2}$ Department of Veterinary Medicine, Faculty of Veterinary Medicine, University of Ilorin, Nigeria.
}

\begin{abstract}
Indigenous poultry production is an essential means of sustaining livelihoods in many parts of sub-Saharan Africa where chicken meat augments dietary needs. However, ectoparasites bedevil its wellbeing. Therefore, this study was designed to document local management practices adopted for ectoparasite control among keepers. A cross-sectional epidemiological survey was carried out using pretested questionnaires to obtain bio-data of keepers and information on management practices. Both body and housing of chickens were combed for ectoparasites and preserved. The specimens were processed following standard parasitological methods and subsequently identified using entomological keys. Descriptive statistics and cross tabulations were employed to process data with statistical significance set at $\mathrm{p}<0.05$. A total of 3,164 birds from 284 keepers (male $69(24.3 \%$ ), female $215(75.7 \%)$ ) were examined out of which 1,125 birds $(38.7 \%)$ were infested $(\mathrm{p}<0.05)$. Among the keepers, $61.6 \%$ were gainfully employed, $8.8 \%$ were farmers and $29.6 \%$ solely depended on poultry for sustenance. The species identified include Menacanthus stramineus 297(52.9\%), Menopon gallinae 132(23.5\%), Lipeurus caponis $88(15.7)$ and Gonoides gigas 44(7.8\%). Two hundred and eighty two (99.3\%) keepers had prior knowledge of ectoparasites $(\mathrm{p}<0.05), 178(62.7 \%)$ identified itching as a prominent symptom of infestation and 270(95.1\%) adopted local treatment methods. Local treatment methods (91.0\% agreed to its reliability) includes; hot ash $(42.6 \%)$, lime leaves $(17.3 \%)$ and Azadairactha indica leaves (15.5\%). The prevalence of these lice species is an attestation to its ubiquity in our locality and the identified management practices suggests immense understanding of its potential constraints to the overall welfare of chicken.
\end{abstract}

Received: 11 Jun 2020

Accepted: 11 Oct 2020

\section{Key words:}

Lice infestation

Management practices

Knowledge

Ilorin Nigeria

Village chicken

*Corresponding author: ope.oa16@yahoo.com

Tel: +2348062100357

\section{Introduction}

Poultry production is a vital arm of livestock industry as it provides source of meat and egg for the ever growing human population (Angyiereyiri et al., 2015). In developed and developing countries, it is on a massive scale with a large number of different poultry species reared every year. In Nigeria, commercial poultry production is a thriving business enterprise providing a reasonable source of income for its rearers, especially during festive seasons. Peridomestic, free range, local, village or backyard poultry production involving the rearing of indigenous domestic fowls (Gallus domesticus) is also not uncommon as they serve household needs and constitute about $85 \%$ of Nigeria's poultry production (Ikpeze et al., 2008a; Nnadi and George, 2010). It is characterized by poor management interventions, feed supplementation, housing, predation and disease control. These setbacks are underlying factors for disease outbreaks and parasite infestation which at times culminate in high bird mortality (Ogada et al., 2016).

Ectoparasites are of great economic importance and constitute a major constraint in indigenous chicken production system (Sychra et al., 2011). Some of the ectoparasites which have been reported in 
chicken are mites, lice, fleas and ticks; notable among them are lice and mites, which are most common and widely spread (Ikpeze et al., 2008a; Ogada et al., 2016). A number of morbidities associated with indigenous chicken are as a result of direct consequences of ectoparasite infestation and may include anaemia, local dermatitis, intense irritation leading to discomfort and weight loss due to inability to eat (Zaria et al., 1996; Bhat et al., 2014). In addition, they impact on body fitness, egg production and hatchability, ability to fly, male courtship behaviour, and long term survival of their host (Sychra et al., 2011). The bite of Argas species and Ixodes brunneus have been linked with tick paralysis; a motor paralysis of voluntary muscles in chicken (Adelusi et al., 2015). Most ectoparasites are vectors/intermediate host for different microbes causing diseases such as fowl pox, pasteurellosis, Newcastle disease, and in some cases Chlamydia (Arends, 2003; Nnadi and George, 2010).

Ectoparasites hide in poor-hygiene poultry houses hence, the high prevalence of infestation in indigenous chicken production could be attributed to poor husbandry and lack of ectoparasite control measures, as chickens are known to roam around homesteads in a bid to scavenge for food leading to spread of ectoparasites when they come into contact with infested birds (Mungube et al., 2008; Sabuni et al., 2010). Recommended control measures for poultry keepers to curb ectoparasitism during outbreaks include good management practices and/or chemical control methods such as dusting, spraying and fumigation of the poultry using selected acaricides, larvicides and fumigants (Mirzaei et al., 2016).

In Nigeria, various species of ectoparasites infesting both exotic and local chicken have been documented. However, the prominent ones include Argas species, Haemophysallis species (ticks); Echidnophaga species (fleas); Menacanthus species, Lipeurus species, Gonoides species, Goniocotes species (lice); and Cnemidocoptes species (mites) (Nnadozie, 1996; Ikpeze et al., 2008b; Bala et al., 2011; Ekpo et al., 2013; Audi and Asmau, 2014; Ahaotu et al., 2019).

Quite a number of studies have reported the prevalence of ectoparasites confronting local chicken production in Nigeria, but very few have addressed keeper's management practices. Therefore, the study was designed to bridge this knowledge gap and proffer better management of ectoparasites which would invariably boost village chicken production.

\section{Materials and Methods}

\subsection{Study Area}

The study was conducted in Ilorin, North Central Nigeria. The city is geographically located on longitude $4^{\circ} 35^{\prime} \mathrm{E}$ and latitude $8^{\circ} 35^{\prime} \mathrm{N}$. The region has two distinct climatic seasons (rainy and dry season) with mean daily temperature ranging between $26.28^{\circ} \mathrm{C}$ and $31.95^{\circ} \mathrm{C}$, and mean annual rainfall of about $1,352 \mathrm{~mm}$. The rainy season starts towards the end of March and ends in October, while the dry season spans from October to February. Inhabitants are predominantly civil servants, traders and farmers with major markets such as Oja-titun, Oja-oba and Ipata located across the city. Tanke Oke-odo, Oko-Oba, Pakata, Tipper garage, Ita-Kure, Gaa-Akanbi, Oke-kura and Ileapa areas of Ilorin were visited during the course of the study.

\subsection{Study Design}

A cross sectional study involving a house to house and market epidemiological survey was carried out between March and June 2018 to determine the extent of ectoparasite infestation of indigenous chicken as well as assess the management practices adopted by rearers. Verbal consent was sought from keepers after a detailed briefing on the study protocol. Well structured, pre-tested questionnaires were used to obtain information such as bio-data of breeder and chicken (sex, breed, colour, and fur texture), housing type, health status of chicken, knowledge of lice infestation and interventions adopted by keepers.

\subsection{Collection of Ectoparasites}

The head, comb, eyelids, wattles, neck, feathers, breast, back, wings, shafts and legs of each bird was thoroughly examined for the presence of tick, flea, louse or mite. Ectoparasite recovery was aided with a hand lens while parting the hairs or feathers and gently brushing with a fine-soft brush to avoid injuries. All recovered ectoparasites were sorted with respect to their type and predilection site. Cracks and crevices within the sleeping areas of the chickens were also examined to avoid omission of parasites with nocturnal activities. Subsequently, all recovered ectoparasites were carefully transferred into pre-labelled universal bottles containing a mixture of $70 \%$ ethanol and $5 \%$ glycerin and transported to the Department of Zoology Parasitology Laboratory, University of Ilorin for processing and species identification.

\subsection{Processing of Ectoparasites}

Ectoparasites were first boiled in $10 \%$ potassium hydroxide $(\mathrm{KOH})$ solution for 15 minutes, dehydrated in ascending concentration of alcohol, cleared in xylene and thereafter mounted in Canada balsam. Permanent slide preparations were viewed under a high power binocular stereo microscope at x40 magnification. The species of ectoparasites were ascertained using entomological guides (Ikeme, 1976; Soulsby, 1982; Walker, 1994). 


\subsection{Statistical Analysis}

Data was coded, entered and analyzed using SPSS (Statistical Package for Social Science) version 21.0. The analysis was carried out by running descriptive statistics and cross tabulations. Values of $\mathrm{P}<0.05$ were considered to be statistically significant.

\section{Results}

A total of 284 keepers (male 69(24.3\%), female $215(75.7 \%)$ took part in this study. The average age of the chicken keepers was 47 years and the ratio of male to female was 24 to 76 . The population of employed village chicken keepers was $61.6 \%$; $8.8 \%$ were farmers and $29.6 \%$ were unemployed as at the time of the survey. It was established that $40.1 \%$ and $13.7 \%$ kept poultry for subsistence and commercial reasons while $46.1 \%$ kept chicken for both purposes.

A total of 3,164 village chickens from different parts of Ilorin were examined for the presence of ectoparasites and 1,225 birds had one form of lice infestation or the other with a point prevalence of $38.7 \%$. The association was statistically significant $(\mathrm{p}<0.05)$. Five hundred and sixty one (561) lice were recovered from the surveyed communities. The species of lice identified include Menacanthus stramineus 297(52.9\%), Menopon gallinae 132(23.5\%), Lipeurus caponis $88(15.7 \%)$ and Gonoides gigas 44(7.8\%) (Figure 1).

The location and percentage population of different lice species recovered in village chicken is shown in (Figure 2). From the carcass of egg, two lice species were recovered, Menopogon gallinae (23\%) and Menacanthus stramineus (38\%); from the thigh and breast region, Gonoides gigas (25\%), Menopogon gallinae (28\%) and Menacanthus stramineus (65\%); from fluff of feathers, Gonoides gigas (22\%), Menopogon gallinae $(57 \%)$ and Menacanthus stramineus (81\%); from neck/back, Menopogon gallinae (54\%) and Menacanthus stramineus (84\%); and from the head/comb, Lipeurus caponis (52\%) and Menacanthus stramineus $(20 \%)$.

The distribution of ectoparasites based on the type of habitation of chicken indicated that all lice species (G. gigas, M. gallinae, L. caponis and $M$. stramineus) were found on chickens that perch around or dwell within households. M. gallinae, $L$. caponis and $M$. stramineus were found on chickens that reside in wooden sheds. However, only two species of lice, G. gigas (10\%) and M. stramineus $(50 \%)$ were found on chicken that lived on bare floor. In general, irrespective of the type of habitation the chicken domiciled, M. stramineus was generally common compared to other lice species. In wooden sheds, L. caponis $(92 \%)$ was more common when compared to others in this group (Figure 3).
Table 1: Population characteristics of the sampled village chicken keepers

\begin{tabular}{lr}
\hline Characteristics & $\mathrm{N}(\%)$ \\
\hline $\begin{array}{l}\text { Population of sampled } \\
\text { chicken keepers }\end{array}$ & 284 \\
$\begin{array}{l}\text { Average age examined } \\
\text { (years) }\end{array}$ & 46.7 \\
$\begin{array}{l}\text { Ratio of male/female } \\
\text { examined }\end{array}$ & $24.3 / 75.7$ \\
Average age of male & \\
examined (years) & 42.3 \\
Average age of female & \\
examined (years) & 48.1 \\
\hline Employment status & $175(61.6)$ \\
\hline Employed & $25(8.8)$ \\
$\begin{array}{l}\text { Farming } \\
\text { Unemployed }\end{array}$ & $84(29.6)$ \\
\hline Purpose for keeping & \\
chicken & $114(40.1)$ \\
\hline Subsistence & $39(13.7)$ \\
Commercial & $131(6.1)$ \\
Both
\end{tabular}

Perception and knowledge of chicken keepers about ectoparasite infestation and control showed that 282(99.3\%), had prior knowledge of ectoparasites in general compared to $0.7 \%$ of those who had faint knowledge. Moreover, a significantly higher number of respondents, 277(97.5\%) were victims, and $6(2.1 \%)$ were informed through the media while $1(0.4 \%)$ keeper acquired knowledge of ectoparasites through research $(\mathrm{P}<0.05)$.

Of those who had knowledge of ectoparasite infestation, 178(62.7\%) identified itching as a prominent symptom of infestation, 101(35.6\%) chose weight loss, while $61(16.0 \%)$ were of the opinion that reduced feeding is a symptom of infestation. However, 48(16.9\%) respondents attributed other unknown symptoms. As regards treatment of chicken, 270(95.1\%) respondents adopted local methods for treating infested birds while $13(4.6 \%)$ keepers do not treat chickens locally (Table 2).

Amongst several local methods used for ectoparasite removal (Figure 4), hot ash (42.6\%) has been frequently used, followed by ewe oronbo (lime leaf) (17.3\%) and Azadairactha indica, commonly known as ewe kashia $(15.5 \%)$. The least method used was hot water $(0.4 \%)$. The frequency with which these methods were used by respondents (Figure 5a) showed that $70 \%$ used at least one of these control methods on a daily basis, while $26 \%$ and $4 \%$ used them on w eekly and monthly basis respectively. 

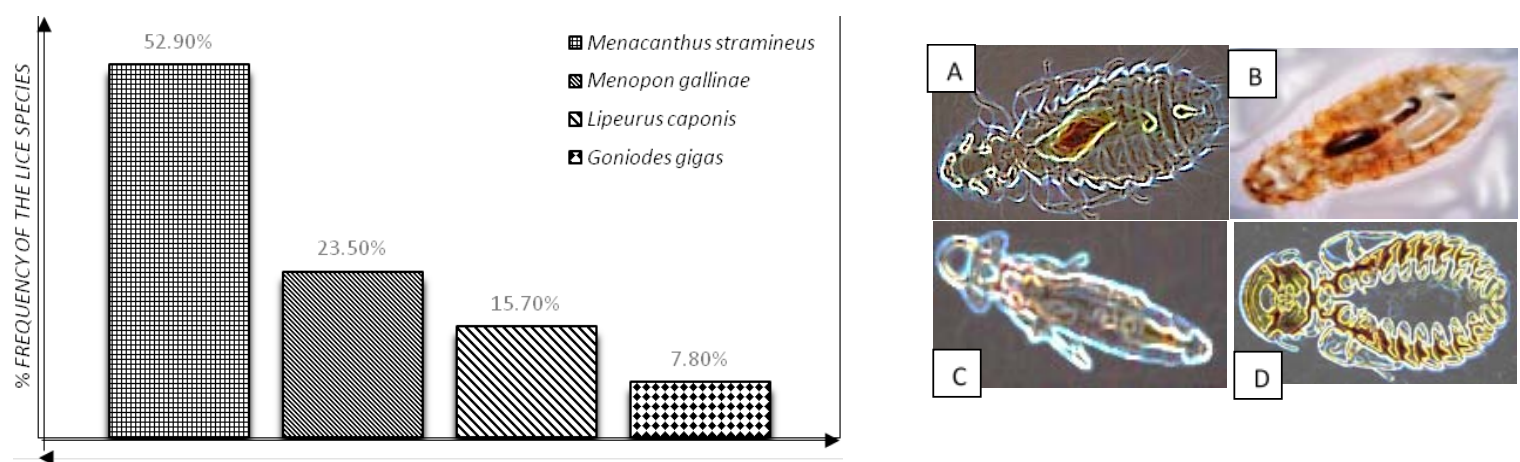

Figure 1: Common Lice species of the village chicken identified in the study area (A: Menacanthus stramineus B: Menopon gallinae, C: Lipeurus caponis and D: Gonoides gigas (Mag. X40)

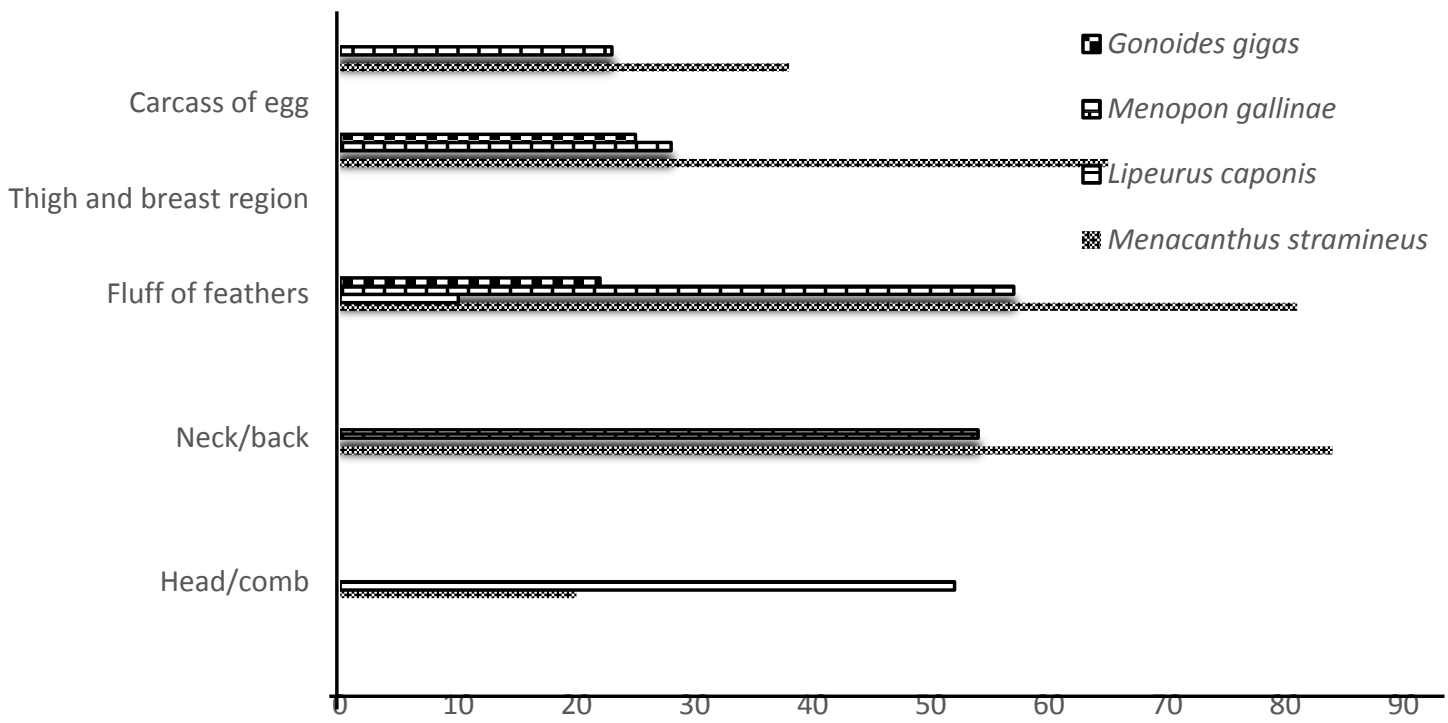

Figure 2: Location and \% population of the different lice species on the village chicken body parts

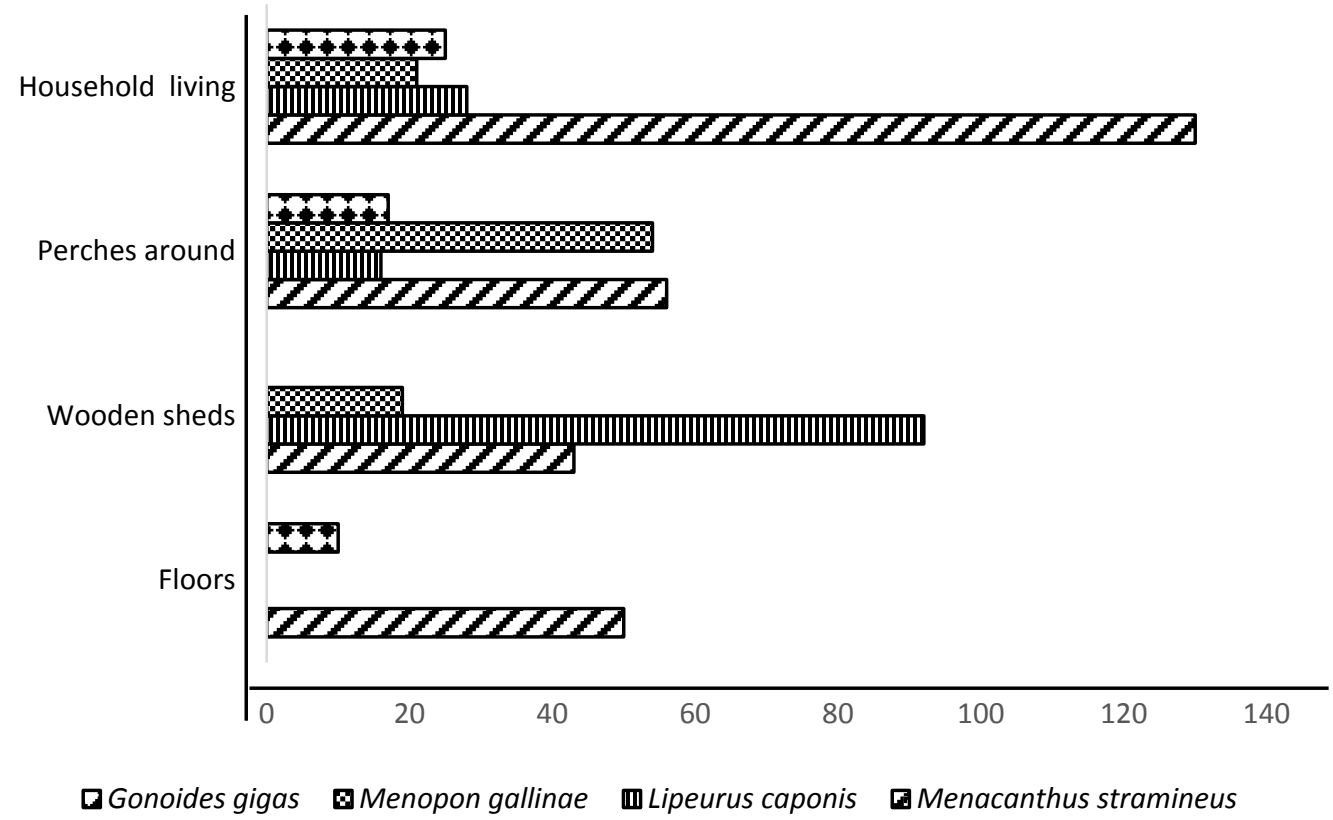

Figure 3: Population distribution of the different lice species with respect to habitation of the sampled village chicken 
A high number of respondents (91\%) considered the local control methods reliable, while $9 \%$ perceived it as unreliable (Figure 5b). This study also revealed that $88.7 \%$ do not use modern drugs.

From the assessment of chicken keeper's perception of the effect(s) of ectoparasites on keepers themselves, $65.8 \%$ picked itching as the greatest effect suffered from ectoparasite infestation of their birds. However, $32.7 \%$, 5.3\% and $8.1 \%$ of keepers chose discomfort, sucking of human blood and other effects (nuisance) respectively, as resultant consequences (Figure 6).

Table 2: Perception and knowledge of the village chicken keepers about lice infestation and control

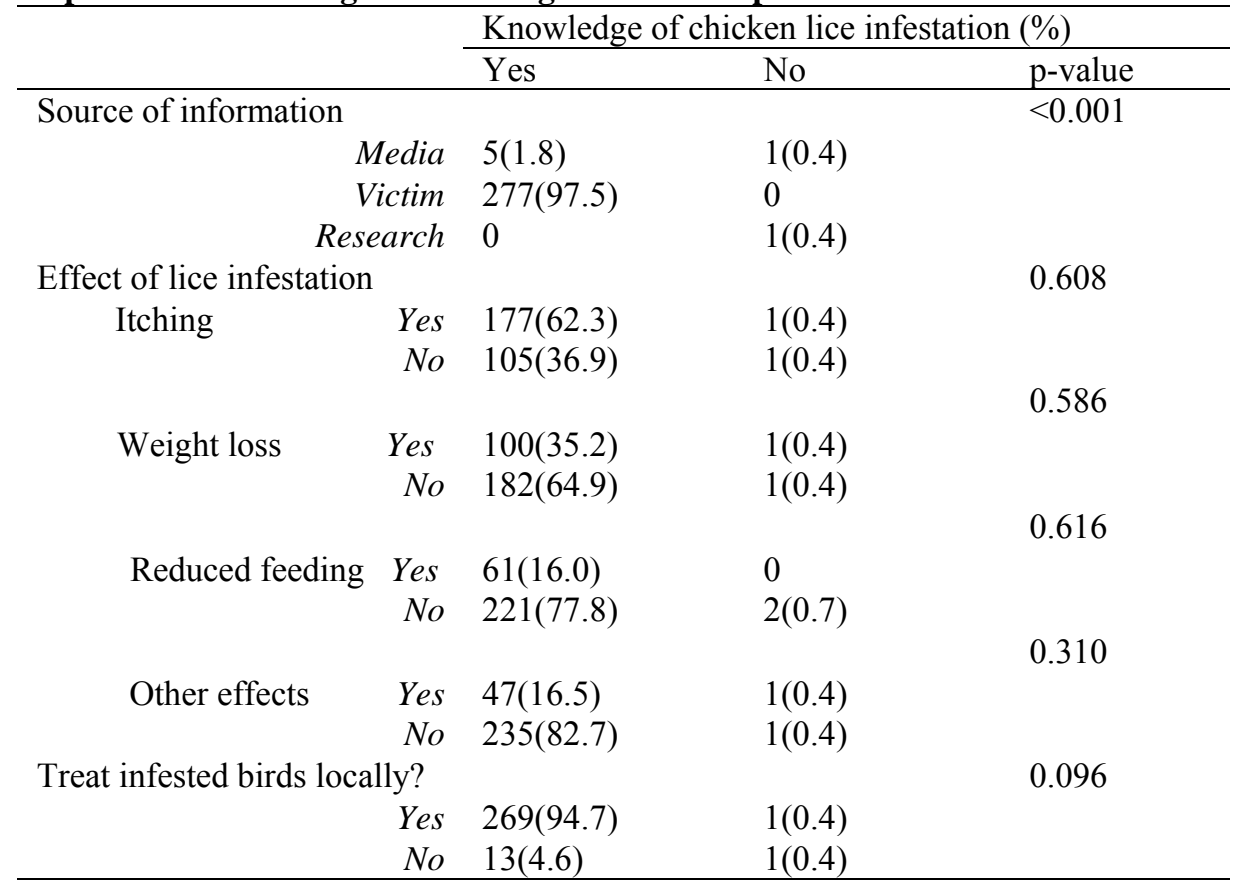

Table 3: Knowledge of ectoparasite infestation and perceived cause and consequence by village chicken keepers

\begin{tabular}{|c|c|c|c|}
\hline & \multicolumn{3}{|c|}{ Knowledge of chicken lice infestation (\%) } \\
\hline & Yes & No & $\mathrm{p}$-value \\
\hline \multicolumn{4}{|l|}{ Observed consequences } \\
\hline Ruffled feather & & & 0.712 \\
\hline Yes & $18(6.3)$ & 0 & \\
\hline No & $264(92.9)$ & $2(0.7)$ & \\
\hline sluggishness & & & 0.413 \\
\hline Yes & $70(24.8)$ & $1(0.4)$ & \\
\hline No & 282(99.3) & $2(0.7)$ & \\
\hline Loss of appetite & & & 0.542 \\
\hline Yes & $85(30.14)$ & $1(0.4)$ & \\
\hline No & $197(69.4)$ & $1(0.4)$ & \\
\hline \multicolumn{4}{|l|}{ Identified causes of lice infestation } \\
\hline Hatching process & & & 0.759 \\
\hline Yes & $171(60.2)$ & $1(0.4)$ & \\
\hline No & $111(39.1)$ & $1(0.4)$ & \\
\hline Dirty Environment & & & 0.602 \\
\hline Yes & $92(32.4)$ & $1(0.4)$ & \\
\hline No & $190(66.9)$ & $1(0.4)$ & \\
\hline
\end{tabular}




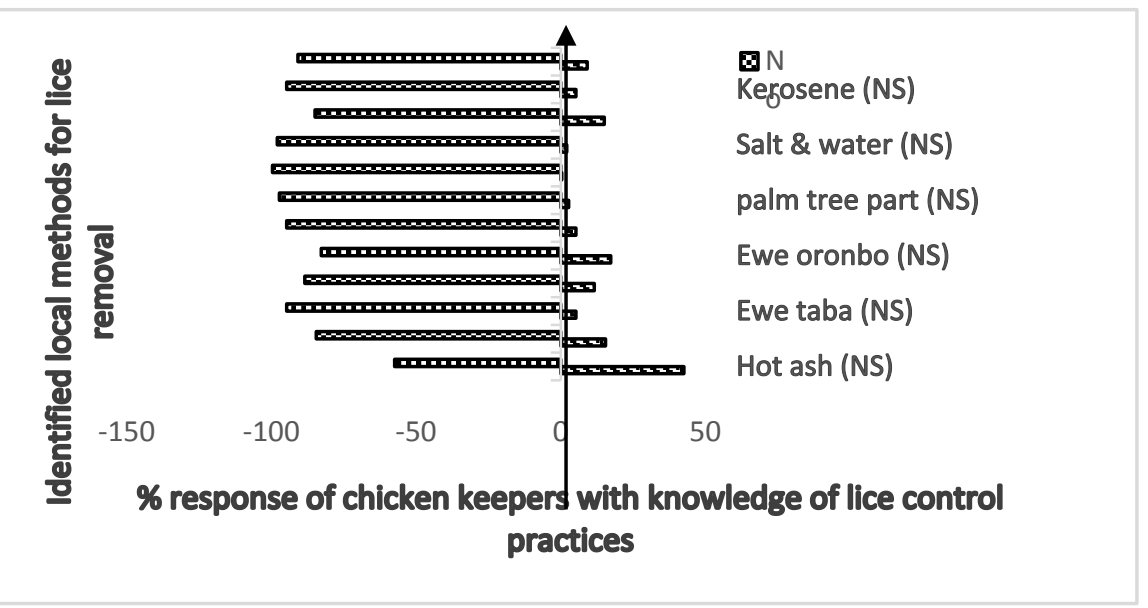

Key: NS - Not significant @ $\mathrm{p}<0.05$

Figure 4: Common lice control practices among village chicken keepers

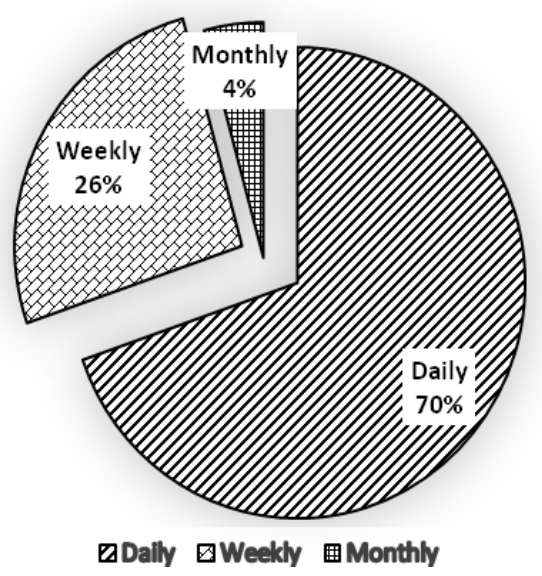

Figure 5a: Percentage frequency of lice control practices by village chicken keepers with respect to duration.

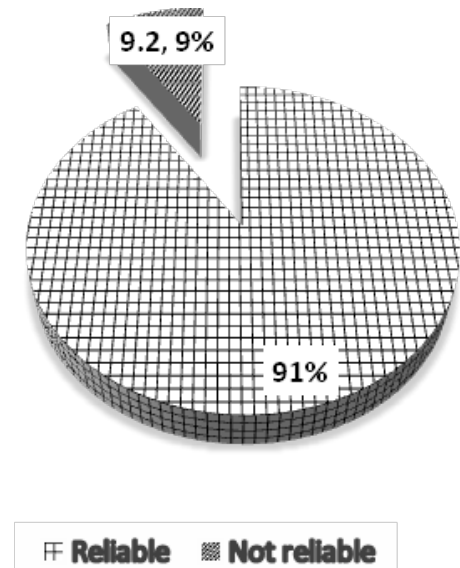

Figure 5b: Village chicken keeper's perception about established local control practices for lice.

를 yes : No
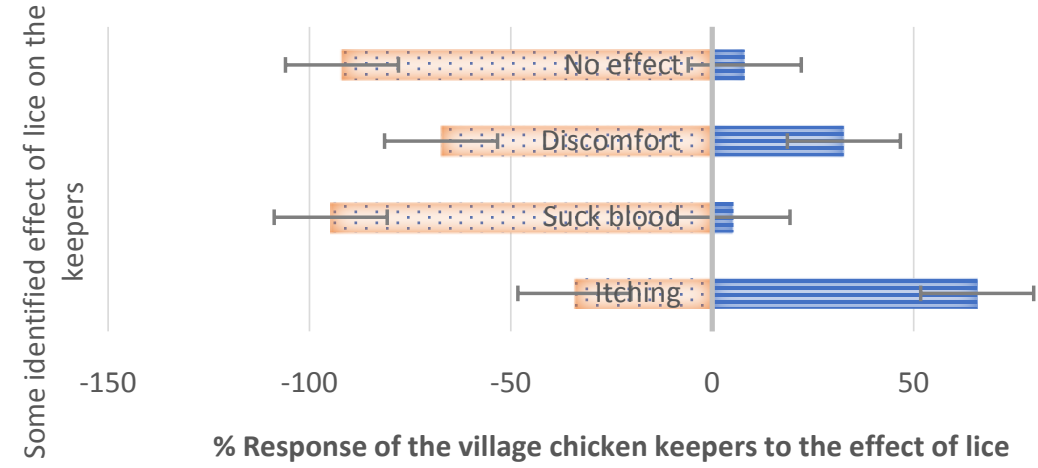

$-100$

$-50$

50

100

\% Response of the village chicken keepers to the effect of lice infestation on them

Figure 6: Village chicken keeper's perception of some identified effect of lice infestations on the keepers

The general knowledge of the causes and effects of lice infestation in chicken as perceived by keepers is shown in Table 3. Some of the identified causes of chicken infestation includes hatching process 
$(171(60.2 \%))$ and dirty environment $(92(32.4 \%))$. A total of $18(6.3 \%), 70(24.8 \%)$ and $85(30.1 \%)$ poultry keepers were of the view that ruffled feather, sluggishness and loss of appetite respectively were observed effects of chicken infestation $(\mathrm{p}>0.05)$.

\section{Discussion}

Ectoparasites have been identified as one of the major impediments to poultry production worldwide. Findings from this study indicated that indigenous chicken rearing are predominantly owned by women $(75.6 \%)$ who are saddled with their care and management. This is consistent with the study from northern Nigeria (El-Yuguda et al., 2007) and Botswana (Moreki and Masupu, 2001). All ectoparasites recovered from chickens were lice as opposed to several studies in which at least 3 out of the 4 major ectoparasite groups viz; lice, ticks, fleas and mites were reported (Adelusi et al., 2015; Ogada et al., 2016; Ahaotu et al., 2019). Lice are known to be the most abundant and widely spread ectoparasites affecting chickens in Nigeria (Nnadi and George, 2010; Malann et al., 2016) and most parts of the world (Firaol et al., 2014; Mirzaei et al., 2016).

Out of the 4 lice species encountered, $M$. stramineus $(52.9 \%)$ was the most abundant. Epidemiological research has shown that it is the most pathogenic hematophagous species affecting birds (Prelezov and Koinarski, 2006). The high prevalence observed in this study agrees with findings from northern Nigeria (Audi and Asmau, 2014) and southern California (Murillo and Mullens, 2016). An assessment of the predilection site for each lice species showed that $M$. stramineus had preference for fluff of feathers, neck/back, and thigh and breast region while $M$. gallinae was predominantly found on fluff of feathers and neck/back. Although all lice feed on feather structures, M. stramineus and M. gallinae also feed on host tissues and blood causing irritation, feather loss and decrease in feather insulation (Murillo and Mullens, 2016).

Variations in the ectoparasite fauna in chicken is often expected due to many factors, particularly housing differences. The high number of lice species recovered from chickens that perch around as well as those in household dwellings and wooden cages as opposed to those kept on bare floor could be because housing structures provide shelter for ectoparasites and also complicate efficient cleaning of poultry houses. A similar finding was put forward by Paliy et al., (2018) where a high number of chicken mite was recovered from wooden coops.

This study also revealed that majority of poultry keepers $(99.3 \%)$ had prior knowledge of ectoparasites. This is expected as $97.5 \%$ had experienced their birds being infested. O ur data showed that keepers (94.7\%) often adopt local methods for treatment; the most frequently used being hot ash. This may be due to the relatively low cost of the material and easy accessibility. Hot ash and other local methods employed by keepers were perceived to be very effective in treating ectoparasites, however, it cannot be ascertained if birds suffer any complication after treatment. Pyrethrin-based insecticides and diatomaceous earth are recommended safe and effective to achieve lice control (Murillo and Mullens, 2016). Itching and discomfort were prominent adverse effects of chicken infestation suffered by keepers, however, it may be intriguing to know that some keepers $(5.3 \%)$ feel chicken ectoparasites suck their blood, an erroneous belief that needs to be debunked since ectoparasites are highly host specific.

Knowledge of the causes and effects of ectoparasite infestation is expedient for keepers in order to properly manage poultry systems. In this study, chicken keepers identified hatching process as a cause of lice infestation and to a lesser extent, dirty environment $(p>0.05)$. Reports have shown that the majority of chicken infestations were associated with poor hygiene of chicken houses and inadequate ectoparasite control practices (Mungube et al., 2008; Sabuni et al., 2010). A higher proportion of chicken keepers do not associate decreased appetite, sluggishness and ruffled feather with ectoparasite infestation. However, it is known that ectoparasites, particularly lice feed on feather structures and host tissues which negatively impacts on host's fitness, productivity and survival.

\section{Conclusions}

Indigenous chicken production systems are at constant risk of ectoparasite infestation; hence the need to curtail its occurrence and spread as it portends to be a very effective tool for providing nutritional security and livelihoods for keepers. The need for periodical inspection of birds cannot be over-emphasized in order to prevent lice population from becoming problematic as well as enhance chicken productivity. A further research to ascertain the effectiveness of hot ash and other local control methods perceived to be highly effective by keepers is exigent in order to rule out any adverse consequences on the wellbeing of chickens.

\section{Acknowledgement}

We sincerely appreciate the undergraduates that assisted in the administration of questionnaire and collection of samples during the survey. We equally thank the community heads and the market women who provided information on 1 ocal lice management practices and allowed us to carry out this study. 


\section{References}

Adelusi, S., Vajime, C., Omudu, E., Okpotu, R., Onazi, F. 2015 Avian Ectoparasitism in Makurdi, Nigeria: Do Wild Birds Serve as Reservior for Domestic Birds? Nigerian Annals of Pure and Applied Sciences 6: 11-15.

Ahaotu, E., Aturuchi, W., Unagu, A., Uzegbu, H. 2019 Economic Importance and Widespread of Ectoparasites Infestation in Indigenous Chickens (Gallus gallus domesticus). A Study from Selected Local Government Councils and States in Nigeria. Sustainability Agriculture Food and Environmental Research 7(2): 17-31

Angyiereyiri, E., Sackey, I., Bonu-Ire, M. 2015 Survey on Arthropod Ectoparasites on Goats and Domestic Fowls in Vunania, Navrongo, Ghana. Canandian Journal of Pure and Applied Sciences 9: 3371-3377.

Arends, J. 2003 External Parasites and Poultry Pests. In: Disease of poultry, 11th edition, (Edited by Calnek, W.B., John, H., Beard, W.C., Mc Dougald, L.R., Saif, Y.M.). Iowa State Press, Blackwell Publishing Company, Ames, Iowa. pp 905-930.

Audi, A., Asmau, A. 2014 Prevalence Of Bird Louse, Menacanthus Cornutus (Pthiraptera: Amblycera) In Four Selected Poultry Farms In Kano State, Nigeria. Bayero Journal of Pure and Applied Sciences 7: 142-146.

Bala, A., Anka, S., Waziri, A., Shehu, H. 2011 Preliminary survey of ectoparasites infesting chickens (Gallus domesticus) in four areas of Sokoto Metropolis. Nigerian Journal of Basic and Applied Sciences 19(2): 173-180

Bhat, A., Wani, Y., Khojuria, K., Katoch, R. 2014 A Rare Report of Ectoparasites in Backyard Poultry in Jammu Region: Prevalance Study and Economic Importance. Asian Journal of Animal and Veterinary Advances 9: 727-731.

Ekpo, U., Ogbooye, A., Oluwole, A., Takeet, M. 2013 A preliminary survey on the parasites of free range chicken in Abeokuta, Ogun State, Nigeria. Journal of Natural Sciences Engineering and Technology 9: 123-130.

El-Yuguda, A., Ngulde, I., Abubakar, M., Baba, S. 2007 Village chicken health, management and production indices in selected villages of Borno State, Nigeria. Family Poultry 17: 4148.

Firaol, T., Dagmawit, A., Askale, G., Solomon, S., Morka, D., Waktole, T. 2014 Prevalence of ectoparasite infestation in chicken in and around Ambo Town, Ethiopia. Journal of Veterinary Science and Technology 5: 189193.
Ikeme, M. 1976 Laboratory Techniques for Verterinary Parasitology and Entomology. Department of Verterinary Parasitology, University of Nigeria Nsukka, pp 63-67

Ikpeze, O., Amagba, I., Eneanya, C. 2008 Preliminary survey of ectoparasites of chicken in Awka, SouthEeastern Nigeria. Animal Research International 5(2): 848-851.

Malann, Y., Olatunji, B., Usman, A. 2016 Ectoparasitic infestation on poultry birds raised in Gwagwalada area council, FCT-Abuja. International Journal of Innovative Research and Development 5: 74-77.

Mirzaei, M., Ghashghaei, O., Yakhchali, M. 2016 Prevalence of ectoparasites of indigenous chickens from Dalahu region, Kermanshah province, Iran. Türkiye Parazitolojii Dergisi 40: $13-18$.

Moreki, J., Masupu, K. 2001 Country report: Botswana. In: SADC Planning Workshop on Newcastle Disease Control in Village Chickens. 6-9 March 2000, Maputo, Mozambique. . Proceedings of an International Workshop (Alders, R.G. and Spradbrow, P.B., Eds.) Australian Centre for International Agriculture Research Proceedings No. 103: 5-10.

Mungube, E., Bauni, S., Tenhagen, B., Wamae, L., Nzioka, S., Muhammed, L., Nginyi, J. 2008 Prevalence of parasites of the local scavenging chickens in a selected semi-arid zone of Eastern Kenya. Tropical Animal Health and Production 40: 101-109.

Murillo, A., Mullens, B. 2016 Diversity and Prevalence of Ectoparasites on Backyard Chicken Flocks in California. Journal of Medical Entomology 53: 707-711.

Nnadi, P., George, S. 2010 A c ross-sectional survey on parasites of chickens in selected villages in the subhumid zones of SouthEastern Nigeria. Journal of Parasitology Research volume 141824 pp 1-6.

Nnadozie, V. 1996 Prevalence of Ectoparasites of Local Chicken in Nsukka Area of Enugu State, Nigeria, University of Nigeria, Nsukka, Nigeria.

Ogada, S., Lichoti, J., Oyier, P. 2016 A survey on disease prevalence, ectoparasite infestation and chick mortality in poultry populations of Kenya. Livestock Research for Rural Development 28(12): 1-5.

Paliy, A., Mashkey, A., Sumakova, N., Paliy, A. 2018 Distribution of poultry ectoparasites in industrial farms, farms, and private plots with 
different rearing technologies. Biosystems Diversity 26: 153-159.

Prelezov, P., Koinarski, V. 2006 Species variety and population structure of Mallophaga (Insecta: Phthiraptera) on chickens in the region of Stara Zagora. Bulg. Journal of Veterinary Medicine 9: 193-200.

Sabuni, Z., Mbuthia, P., Maingi, N., Nyaga, P., Njagi, L., Bebora, L., Michieka, J. 2010 Prevalence of ectoparasites infestation in indigenous free-ranging village chickens in different agro-ecological zones in Kenya. Livestock Research for Rural Development 22: $1-4$.

Soulsby, E. 1982 Helminths, Arthropods and Protozoa of Domesticated Animals. Balliere, Tindall and Cassel, London, 809 p.

Sychra, O., Literak, I., Podzemny, P., Harmat, P., Hrabak, R. 2011 Insect ectoparasites on w ild birds in the Czech Republic during the prebreeding period. Parasites 18: 13-19.

Walker, A. 1994 The Arthropods of human and domestic animals. A guide to preliminary identification. Chapman and Hall London, 109 p.

Zaria, L., Sinha, P., Natiti, L., Nawathe, D. 1996 Incidence of ectoparasites of domestic fowl in an arid zone of Nigeria. Nigerian Journal of Animal Production 23: 91-93. 